\title{
Efek Panjang Gelombang Terhadap Pertumbuhan Propagul Pada Kultur Jaringan Eucheuma cottonii Doty, 1885 (Rhodophyceae; Solieracea)
}

\author{
Wilis Ari Setyati1*, Rini Pramesti', Delianis Pringgenies', Chrisna Adhi Suryono', \\ Irwani ${ }^{1}$, Muhammad Zainuddin ${ }^{2}$ \\ 'Departemen IImu Kelautan, Fakultas Perikanan Dan IImu Kelautan, Universitas Diponegoro \\ Jl. Prof Soedarto, SH., Tembalang, Semarang 50275 Indonesia \\ 2 Program Studi Akuakultur, Fakultas Sain Dan Teknologi, Universitas Islam Nahdlatul Ulama Jepara \\ Jl. Taman Siswa, Pekeng, Tahunan, Jepara, Jawa Tengah 59451 Indonesia \\ Email: wilisarisetyati@yahoo.co.id
}

\begin{abstract}
The Effect of Wavelength on Growth of Propagule Eucheuma cottonii Doty Tissue Culture, 1885 (Rhodophyceae; Solieracea)
\end{abstract}

The problem in cultivating Eucheuma cottonii is the procurement of seeds and techniques currently developed through tissue culture. The limiting factor in this technique is the use of optimal light for the growth of the seaweed. The aims of study was to optimize the wavelength of light on the growth of $E$ cottonii propagules. The research method is laboratory experimental with the treatment of different wavelengths of light: red light wavelength $(\lambda=633.8 \mathrm{~nm})$, green $(\lambda=515.8 \mathrm{~nm})$, blue $(\lambda=$ $455.7 \mathrm{~nm})$, combined light on the lamp LED $(\lambda=456.6 \mathrm{~nm}, 515.8 \mathrm{~nm}$ and $632.9 \mathrm{~nm})$, and fluorescent light in TL lamps ( $\lambda=407 \mathrm{~nm}, 443 \mathrm{~nm}, 557 \mathrm{~nm}$ and $592 \mathrm{~nm}$ ). The results showed that the wavelength had a significant effect ( $p \leq 0.05$ ) on the growth of $E$ cottonii. The best treatment for blue light with absolute, relative and specific growth values of propagule weight of $155 \pm 11.910 \mathrm{mg}, 419 \pm 70.849 \%$, and $5.860 \pm 0.501 \%$ / day. The absolute, relative and specific growth values for propagule diameter were $701 \pm 123.1 \mathrm{~mm}, 63 \pm 12 \%$ and $1.73 \pm 0.27 \%$ / day. The percentage of branching growth and the branching index were $60.85 \pm 9.16 \%$ and $27.77 \pm 1.23$. Blue light treatment is optimal radiation in the E. cottonii tissue culture

Keywords: light; growth; propagul

\begin{abstract}
Abstrak
Permasalahan dalam budidaya Eucheuma cottonii adalah pengadaan bibit dan teknik yang berkembang saat ini melalui kultur jaringan. Faktor pembatas dalam teknik ini adalah penggunaan cahaya yang optimal untuk pertumbuhan rumput laut. Penelitian bertujuan untuk melakukan optimasi panjang gelombang cahaya terhadap pertumbuhan propagul E cottonii. Metode penelitian secara experimental laboratoris dengan perlakuan perbedaan panjang gelombang cahaya : panjang gelombang lampu cahaya merah $(\lambda=633,8 \mathrm{~nm})$, hijau $(\lambda=515,8 \mathrm{~nm})$, biru $(\lambda=$ $455,7 \mathrm{~nm})$, cahaya gabungan pada lampu LED $(\lambda=456,6 \mathrm{~nm}, 515,8 \mathrm{~nm}$ dan $632,9 \mathrm{~nm})$, dan cahaya flourescent pada lampu TL ( $\lambda=407 \mathrm{~nm}, 443 \mathrm{~nm}, 557 \mathrm{~nm}$ dan $592 \mathrm{~nm}$ ). Hasil penelitian menunjukkan bahwa panjang gelombang berpengaruh signifikan $(p<0,05)$ terhadap pertumbuhan $E$ cottonii. Perlakuan terbaik pada cahaya biru dengan nilai pertumbuhan mutlak, relatif dan spesifik bobot propagul sebesar $155 \pm 11,910 \mathrm{mg}, 419 \pm 70,849 \%$, dan $5,860 \pm 0,501 \%$ /hari. Nilai pertumbuhan mutlak, relatif dan spesifik diameter propagul sebesar $701 \pm 123,1 \mathrm{~mm}, 63 \pm 12 \%$ dan $1,73 \pm 0,27 \%$ /hari. Persentase pertumbuhan percabangan dan indeks percabangan sebesar $60,85 \pm 9,16 \%$ dan $27,77 \pm 1,23$. Perlakuan sinar biru merupakan penyinaran optimal dalam kultur jaringan $E$. cottonii.
\end{abstract}

Kata kunci: cahaya; pertumbuhan; propagul 


\section{PENDAHULUAN}

Indonesia merupakan daerah penghasil rumput laut terbesar di daerah tropis dan nomor dua setelah China (FAO, 2014 dan FAO, 2018). Budidaya rumput laut secara komersial dimulai tahan 1987 di Bali dan pada tahun 2007 Indonesia telah menggantikan Filipina sebagai penghasil karagenan (FAO, 2014; Bixler \& Porse, 2011). Meningkatnya produksi karagenan disebabkan meningkatnya jumlah petani dan luas lahan budidaya bukan karena produktifitasnya yang tinggi (Bixler \& Porse, 2011; Neish 2013). Eucheuma hidup di seluruh kawasan Indo-Pasifik dari Afrika Timur, Guam, perairan Cina dan Jepang dan sebagian besar di daerah terumbu karang di pulau- pulau di Asia Tenggara (Doty, 1987). Rumput laut sekarang banyak diteliti karena tingginya kandungan polisakarida, rata rata kandungan karbohidrat antar $30-80 \%$ dari berat kering (Bouanati et al., 2020). Rumput laut merupakan reservoir biomolekul yang tidak ada habisnya dengan berbagai fungsi dan komponen agar yang berbeda seperti protein, vitamin, mineral, karbohidrat, pigmen dan lemak yang saat ini menjadi alternatif industri makanan, kosmestik maupun farmasi (Yakob et al., 2014; $X u$ et al, 2017). Peningkatan kebutuhan alga coklat di dunia karena digunakan untuk keperluan produksi makanan, farmasi maupun sintesa produk lain seperti anti mikroba dan pathogen dan bahan bakar (biofieul (Zemke-White \& Ohno.,1999; FAO, 2012; Vatsos \& Rebours, 2015; Thanigaivel et al., 2016). Peningkatan kebutuhan rumput laut jenis alga coklat seperti Eucheuma maupun Gracilaria hanya dapat dipenuhi melalui usaha budidaya baik di laut maupun di tambak (Suryono et al., 2020). Peningkatan kebutuhan rumput laut budidaya telah berkembang beberapa decade terakir. Jumlah rumput laut yang dibudidayakan meningkat dari 6,5 juta ton pada tahun 2001 menjadi 15,5 juta ton pada tahun 2010. Nilai rumput laut pada tahun tersebut meningkat dari US \$1.768 juta menjadi US \$4.143 kontribusi dari rumput laut merah (57\%) dan coklat (43\%) (FAO,2013; Ghadiryanfar, 2016).

Peningkatan budidaya rumput laut yang semakin meningkat untuk kebutuhan industri tentunya harus diikuti ketersediaan bibit baik secara vegetative maupun generative. Permasalahan dalam budidaya salah satunya adalah ketersediaan bibit yang mempunyai kualitas bagus (Suryati \& Mulyaningrum, 2009). Salah satu teknik menyediakan bibit secara vegetative adalah dengan kultur jaringan. Kultur jaringan memiliki keunggulan diantaranya dapat diproduksi dalam jumlah banyak dan tidak tergantung musim (Yokoya \& YoneshigueValentin, 2011). Bibit selalu tersedia, identik dengan induknya, kesehatan bibit lebih terjamin, dan dapat tumbuh dengan cepat saat dibudidaya (Yildiz, 2012). Bibit unggul telah banyak didapatkan dari cara kultur jaringan (Mulyaningrum et al., 2012; Sulistiani et al., 2012). Keberhasilan budidaya rumput laut tidak hanya oleh bibit namun juga oleh kondisi lingkungan seperti salinitas, cahaya, suhu maupun nutrient. Faktor cahaya sangat berpengaruh dalam penyediaan bibit secara kultur jaringan terutama untuk pertumbuhan dan produksi bibit. Namun cahaya sendiri memiliki banyak panjang gelombang dan tidak semuanya dapat digunakan oleh tumbuhan (Hurd et al., 2014). Beberapa penelitian gelombang cahaya terhadap rumput laut telah dilakukan. Panjang gelombang cahaya berpengaruh pada efisiensi fotosintesis Houttuynia cordata (Wang et al., 2015). Cahaya juga berpengaruh terhadap nilai pertumbuhan Undaria pinnatifida (Takahide et al., 2017). Cahaya dengan berbagai warna dengan panjang gelombang tertentu berpengaruh terhadap nilai pertumbuhan dan fitokimia Pyropia haitanensis (Wu, 2016). Aplikasi cahaya sudah dilakukan pada beberapa rumput laut namun belum pernah dilakukan pada E. cottonii, sehingga penelitian ini bertujuan untuk mengetahui panjang gelombang cahaya optimal dalam kultur jaringan E. cottonii

\section{MATERI DAN METODE}

Penelitian ini menggunakan propagul rumput laut E. cottonii hasil kultur jaringan dari Laboratorium SEAMEO Bogor. Induk diperoleh dari petani rumput laut di Kabupaten Natuna, Propinsi Kepulauan Riau. Kultur dalam penelitian ini menggunakan air laut steril 30 ppt dan media air laut yang diperkaya (Pramesti, 2013). Propagul E. cottonii yang digunakan adalah hasil aklimatisasi yang 
sehat, tidak terdapat bercak, tidak terkelupas, talus elastis dan seragam. Propagul dipelihara dalam botol duran dengan kepadatan 10 propagul, media $500 \mathrm{ml}$, media air laut diperkaya $20 \mathrm{ml} / \mathrm{l}$, salinitas 30-32 ppt, suhu 24-

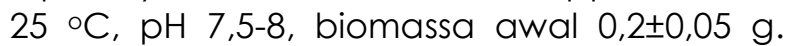
Pemeliharaan diberikan aerasi, penyinaran cahaya gelap : terang $=12: 12$ jam dengan intensitas 2500 lux.

Perlakuan penelitian berupa panjang gelombang dan masing perlakuan dengan empat ulangan. Jenis perlakuannya adalah lampu cahaya merah $(\lambda=633,8 \mathrm{~nm})$, lampu cahaya hijau $(\lambda=515,8 \mathrm{~nm})$, lampu cahaya biru $(\lambda=455,7 \mathrm{~nm})$, cahaya gabungan pada lampu LED ( $\lambda=456,6 \mathrm{~nm}, 515,8 \mathrm{~nm}$ dan 632,9 $\mathrm{nm})$, dan cahaya flourescent pada lampu TL ( $\lambda=407 \mathrm{~nm}, 443 \mathrm{~nm}, 557 \mathrm{~nm}$ dan $592 \mathrm{~nm}$ ). Parameter yang diamati seperti: (1) Pertumbuhan mutlak dan relatif propagul rumput laut E. cottonii (Hendri et al., 2017). (2) Pertumbuhan spesifik (SGR) propagul rumput laut E. cottonii. (3) Pengamatan dan pengukuran diameter propagul (Fadilah \& Dhini, 2016). Data yang diperoleh dilakukan analisa ragam dengan menggunakan SPSS 16.0. Analisis regresi digunakan untuk melihat hubungan antara panjang gelombang 455,7 $\mathrm{nm}$ (biru), 515,8 nm (hijau) dan 633,8 nm (merah) terhadap respon propagul dan melihat hubungan antara persentase komposisi warna biru pada perlakuan yaitu 32 \% (fluorescent), 61 \% (gabungan / LED) dan $100 \%$ (lampu biru) terhadap respon propagul.

\section{HASIL DAN PEMBAHASAN}

Berat propagul merupakan parameter biometri yang digunakan untuk mendiskripsikan pertumbuhan rumput laut. Data tersebut selanjutnya dihitung pertumbuhan mutlak, relatif dan spesifik. Hasil perhitungan rata-rata pertumbuhan mutlak, pertumbuhan relatif dan laju pertumbuhan spesifik propagul E. cottonii (Gambar 1). Hasil penelitian menunjukkan perlakuan perbedaan panjang gelombang cahaya berpengaruh secara signifikan $(p \leq 0,05)$ terhadap pertumbuhan mutlak. Selang data pertumbuhan mutlak antara 34,6 - 145,4 mg. Hasil uji Duncan menunjukkan perbedaan respon pertumbuhan yang nyata $(p \leq 0,05)$ pada setiap perlakuan. Jika data rata-rata pertumbuhan mutlak bobot di urutkan dari tertinggi ke terendah adalah cahaya biru

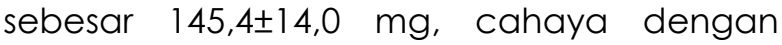
lampu LED (114,1 $\pm 7,2 \mathrm{mg})$, cahaya dengan lampu flourescent $(84,9 \pm 3,4 \mathrm{mg})$, cahaya merah $(71,8 \pm 2,3 \mathrm{mg})$, cahaya warna hijau $(34,6 \pm 3,7 \mathrm{mg})$.

Pertumbuhan bobot mutlak propagul merupakan pertambahan bobot karena bertambahnya sel yang selanjutnya menjadi jaringan. Jaringan akan membentuk organ dan ini dapat menambah bobot biomassa. Fotosintesis menghasilkan oksigen dan karbohidrat sebagai bahan penyusun sel dan cadangan makanan. Semakin tinggi fotosintesis yang maka pertumbuhan akan meningkat. Hal ini sesuai (Hurd et al., 2014) kloroplast mengandung beberapa pigmen diantaranya klorofil a yang berfungsi menyerap cahaya biru-violet dan merah. Cahaya digunakan tumbuhan dalam proses fotosintesis, dengan intensitas cahaya yang cukup maka perubahan senyawa anorganik menjadi senyawa organik juga akan berlangsung optimal dan pertumbuhannya menjadi lebih cepat (Pramesti, 2013). Ditambahkan Wu (2016) panjang gelombang cahaya mempengaruhi nilai pertumbuhan dan fitokimia alga.

Perlakuan perbedaan panjang
gelombang cahaya dalam kultur berpengaruh secara signifikan $(p \leq 0,05)$ terhadap pertumbuhan relatif dan laju pertumbuhan spesifik (SGR) propagul. Data pertumbuhan relatif yang didapatkan memiliki selang 110-419\% dan SGR dengan selang 2,649-5,860 \%/hari. Uji Duncan menunjukkan respon pertumbuhan relatif dan SGR adalah berbeda nyata $(p \leq 0,05)$ pada setiap perlakuan. Respon pertumbuhan relatif tertinggi dan SGR tertinggi adalah pada perlakuan pemberian pencahayaan warna biru yaitu sebesar $419 \pm 70,849 \%$ dan $5,860 \pm 0,501 \% /$ hari. Respon pertumbuhan relatif tertinggi dan SGR tertinggi pada perlakuan cahaya hijau yaitu $110 \pm 10,670 \%$ dan 2,649 $\pm 0,183 \% /$ hari. Berdasarkan data pertumbuhan mutlak, relatif dan SGR tersebut diduga terdapat hubungan antara perlakuan penyinaran terhadap respon pertumbuhan. Hasil analisis regresi antara perlakuan terhadap respon (Gambar 2). 


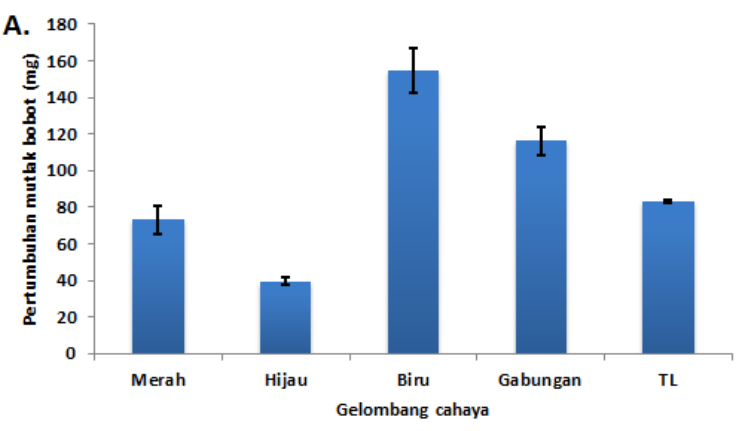

Pertumbuhan mutlak bobot $(\mathrm{mg})$

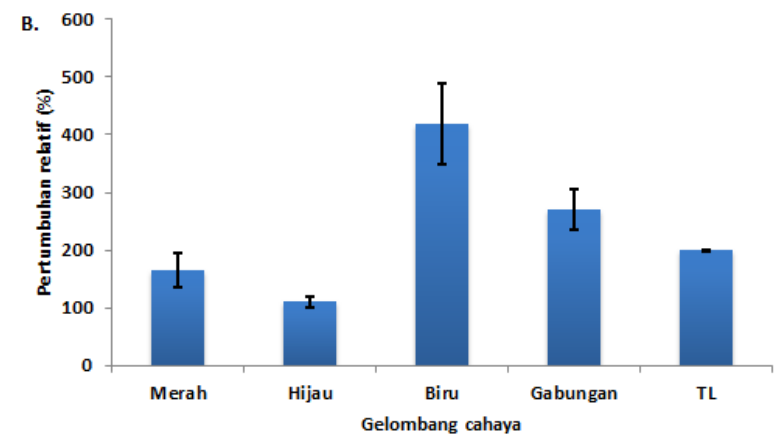

Pertumbuhan relatif (\%)

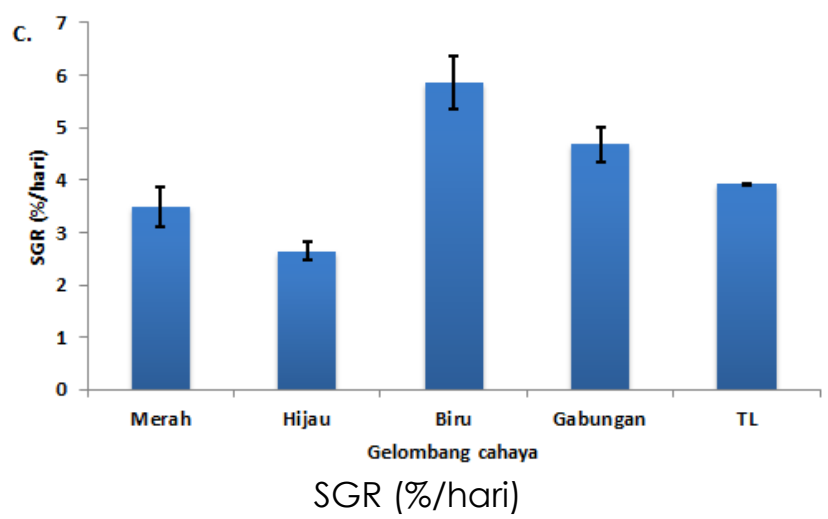

Gambar 1. Pengaruh panjang gelombang terhadap pertumbuhan propagul

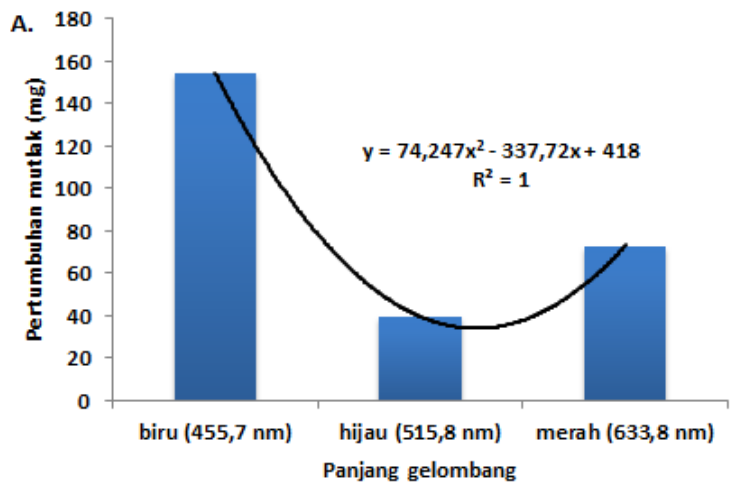

Panjang gelombang $(\mathrm{nm})$

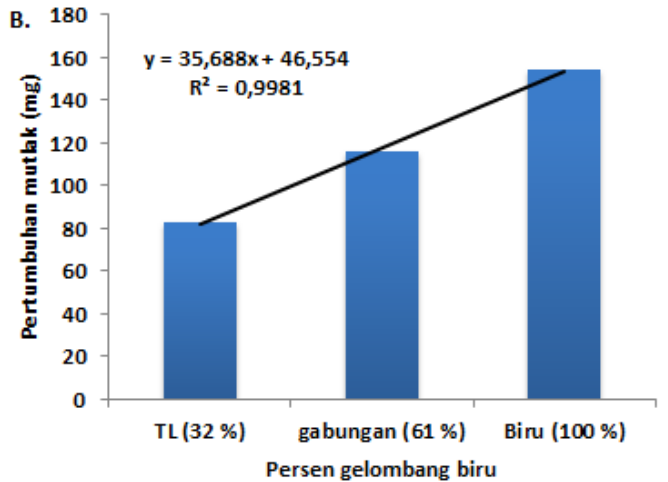

Persentase komposisi gelombang biru (\%)

Gambar 2. Hubungan panjang gelombang terhadap pertumbuhan propagul

Berdasarkan analisis regresi antara panjang gelombang $455,7 \mathrm{~nm}$ (biru), $515,8 \mathrm{~nm}$ (hijau) dan 633,8 nm (merah) terhadap respon pertumbuhan mutlak propagul menunjukkan adanya hubungan regresi non linier berbentuk parabola negatif yaitu semakin tinggi panjang gelombang maka pertumbuhan mutlak semakin turun dan selanjutnya pertumbuhan mutlak kembali mengalami kenaikan. Pertumbuhan mutlak tertinggi terdapat pada cahaya biru.

Hasil uji regresi linier pada persentase komposisi warna biru pada perlakuan 
terhadap respon pertumbuhan mutlak propagul menunjukkan terdapat hubungan regresi linier sederhana yaitu semakin tinggi komposisi warna biru maka pertumbuhan mutlak semakin tinggi. Berdasarkan hasil penelitian rata-rata pertumbuhan mutlak bobot tertinggi pada panjang gelombang cahaya 455,7 nm dengan warna biru. Penelitian Godinez-Ortega (2008) yang menguji pertumbuhan rumput laut merah dengan pemberian panjang gelombang berbeda dan pertumbuhan tertinggi pada cahaya biru. Cahaya berwarna biru merupakan cahaya yang diserap chlorophylla. Ditambahkan (Hurt et al., 2014) konsentrasi klorofil yang tinggi pada rumput laut akan menyerap energi cahaya dengan jumlah yang banyak. Ditambahkan Packer (2009) efisiensi fotosintesis didefinisikan sebagai persentase radiasi cahaya yang diubah menjadi biomassa. Okumura et al. (2015) bahwa cahaya monokromatik berwarna biru menghasilkan laju pertumbuhan dan biomasa tertinggi pada Botryococcus braunii. Menurut Wu (2016) cahaya pada panjang gelombang warna biru memiliki efisiensi fotosintesis tertinggi pada rumput laut merah. (Matthijs et al., 1996) menyatakan enzim yang terlibat dalam metabolisme karbohidrat diatur oleh cahaya warna biru.

Data morfologi propagul yang terdiri dari data diameter talus dan percabangan propagul. Adapun hasil perhitungan pertumbuhan mutlak, relatif dan spesifik diameter talus propagul E.cottonii tersaji pada Gambar 3.

Hasil penelitian menunjukkan perbedaan panjang gelombang berpengaruh secara signifikan $(p \leq 0,05)$ terhadap pertumbuhan diameter talus baik mutlak, relatif dan SGR. Uji Duncan menunjukkan perbedaan respon pertumbuhan diameter talus yang nyata $(p \leq 0,05)$ pada setiap perlakuan.

Cahaya warna biru memiliki respon pertumbuhan mutlak, relatif dan SGR diameter talus tertinggi yaitu secara berurutan sebesar $701 \pm 123,1 \mathrm{~mm}, 63 \pm 12 \%$ dan $1,73 \pm 0,27$ $\% /$ hari. Berdasarkan data pertumbuhan mutlak, relatif dan SGR diameter talus menunjukkan terdapat hubungan antara perlakuan penyinaran terhadap respon diameter talus (Gambar 4).

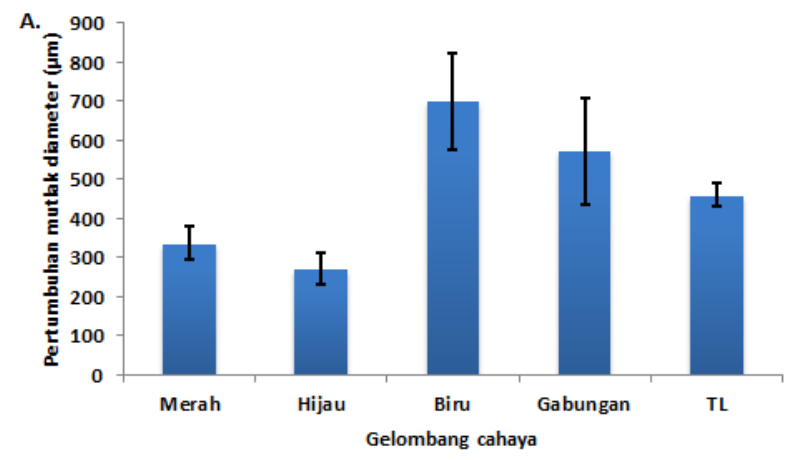

Pertumbuhan mutlak diameter

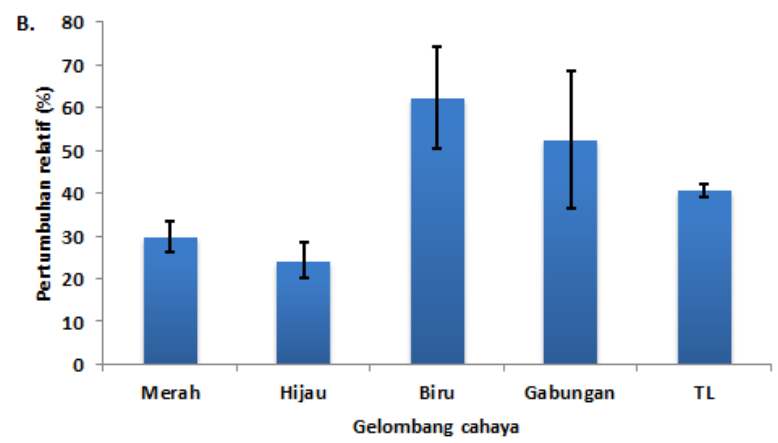

Pertumbuhan relatif diameter.

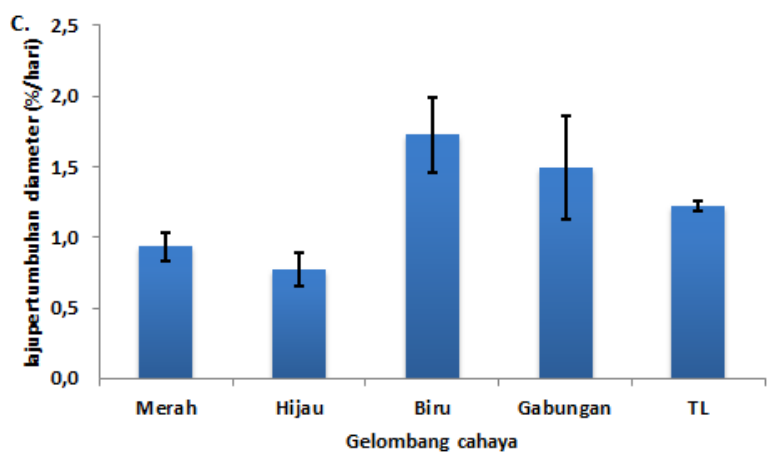

Laju pertumbuhan diameter

Gambar 3. Pengaruh panjang gelombang terhadap diameter propagul 
Pertambahan diameter talus yang besar diduga fotosintesis yang optimal dan laju pertumbuhan yang tinggi juga. Hurt et al. (2014) panjang gelombang yang sesuai dapat menjaga proses fotosintesis terus berlangsung termasuk pembelahan sel yang menambah ukuran tanaman. Mulyaningrum et al. (2012) diameter batang bertambah karena tumbuhnya jaringan meristem diantaranya meristem lateral yang terletak di organ yang mengalami pelebaran. Meristem lateral menghasilkan sel-sel baru yang memperpanjang diameter talus dan memperluas permukaan talus.

Besarnya luas permukaan diduga propagul pada perlakuan panjang gelombang biru lebih efisien dalam menyerap cahaya yang dibutuhkan dalam proses fotosintesis. Ditambahkan Stewart \& Carpenter (2003) laju fotosintesis bersih dari biomassa spesifik rumput laut meningkat dengan semakin meningkatnya rasio luas

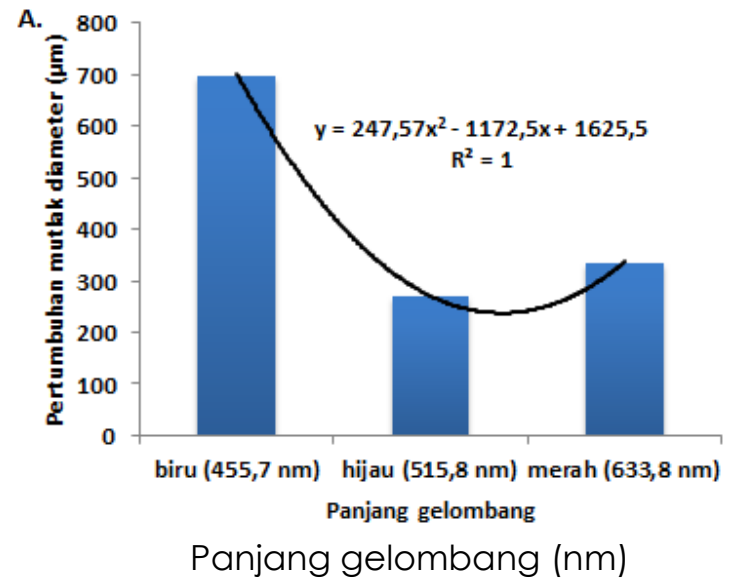

permukaan: volume talus. Tingginya serapan cahaya oleh propagul pada perlakuan panjang gelombang biru akan diikuti tingginya laju fotosintesis, yang meningkatkan laju penyerapan karbon serta laju pertumbuhannya. Laju pertumbuhan yang meningkat mempengaruhi pembesaran diameter dan cabang propagul.

Hasil penelitian tentang morfologi percabangan yang terdiri persentase dan indek pembentukan percabangan. Adapun hasil analisis data pembentukan percabangan, persentase dan indek percabangan propagul (Gambar 5).

Perlakuan cahaya dengan fluorescent (lampu TL) memiliki respon persentase pembentukan percabangan propagul tertinggi sebesar $61,70 \pm 13,26 \%$ dan terendah pada cahaya gabungan (lampu LED) sebesar $30,36 \pm 7,01 \%$. Jika data indeks percabangan propagul di urutkan dari tertinggi ke terendah

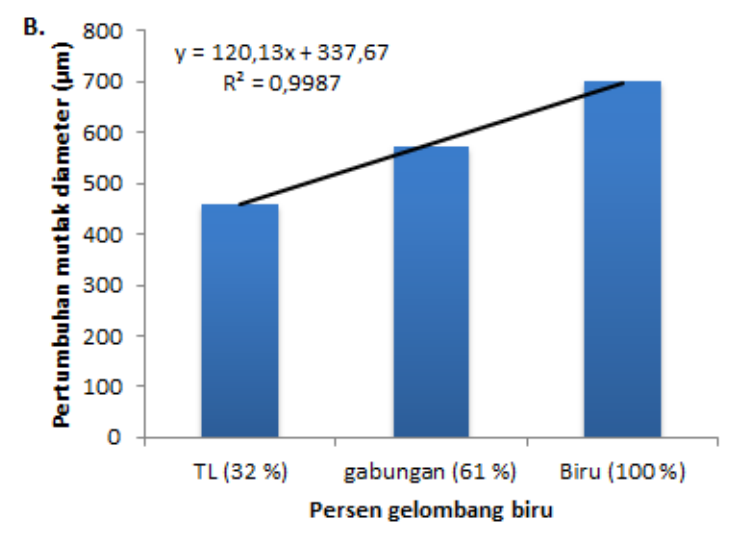

Persentase komposisi gelombang biru (\%)

Gambar 4. Hubungan panjang gelombang terhadap pertumbuhan mutlak diameter

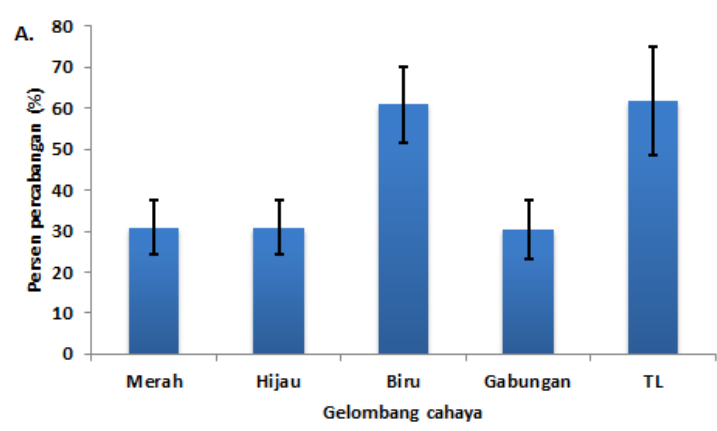

Persen percabangan

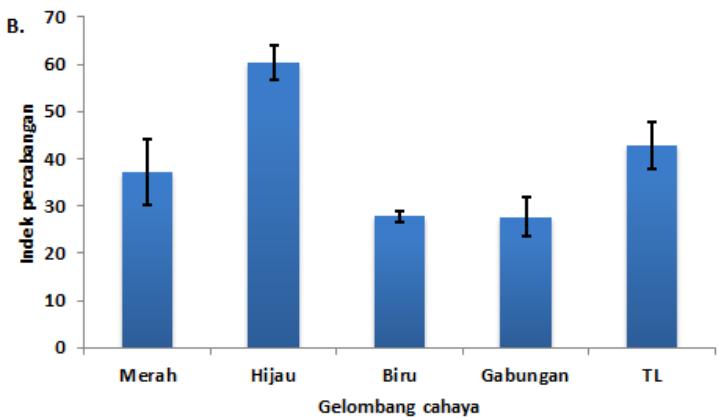

Indeks percabangan

Gambar 5. Pengaruh panjang gelombang terhadap pertumbuhan percabangan propagul. 
adalah yang tertinggi perlakuan cahaya hijau, fluorescent (lampu TL), cahaya merah, cahaya biru dan cahaya gabungan (lampu LED). Perlakuan cahaya hijau memiliki indek percabangan tertinggi yaitu 60,45 $\pm 3,67$, sedangkan cahaya gabungan (lampu LED) terendah yaitu $27,64 \pm 4,20$.

Berdasarkan hasil penelitian diperoleh hasil tertinggi pada perlakuan panjang gelombang cahaya warna biru. Hal ini diduga gelombang cahaya biru berperan dalam pertumbuhan maupun proses metabolisme sel. Gelombang cahaya dalam penelitian ini menghasilkan respon berbeda terhadap perubahan morfologi. Hurd et al. (2014) panjang gelombang cahaya yang sesuai dapat menjaga proses fotosintesis terus berlangsung termasuk pembelahan sel yang menambah ukuran tanaman dan pembentukan tunas, sehingga dapat mengoptimalkan pembentukan tunas. Pertumbuhan yang optimal ini dapat mensintesis berbagai hasil seperti pembentukan hormon yang memacu pertumbuhan maupun pembentukan organ tanaman.

Pertumbuhan cabang merupakan hasil dari pembelahan dan pembesaran sel yang terjadi di jaringan meristem. Jaringan meristem adalah jaringan yang bersifat embrionik, yaitu sel-selnya mempunyai kemampuan membelah diri secara terus-menerus. Mulyaningrum et al. (2012) jaringan meristem terdapat di ujung dan interkalar. Meristem ujung terletak di ujung akar atau batang. Meristem interkalar terletak diantara jaringan yang terdiferensiasi. Meristem yang di bagian ujung menghasilkan sel-sel baru di ujung talus rumput laut sehingga talus bertambah panjang. Meristem interkalar memberi pemanjangan sel-sel di ruas-ruas cabang.

\section{KESIMPULAN}

Perlakuan panjang gelombang cahaya berpengaruh signifikan $(p \leq 0,05)$ terhadap pertumbuhan dan morfologi propagul Eucheuma cottonii. Pertumbuhan bobot, diameter talus dan persentase percabangan terbaik pada perlakuan cahaya biru dengan panjang gelombang 455,7 nm.

\section{UCAPAN TERIMAKASIH}

Kami mengucapkan terimakasih kepada pemberi dana yang bersumber dari selain APBN DPA LPPM, Universitas Diponegoro Tahun Anggaran 2019.

\section{DAFTAR PUSTAKA}

Bixler, H.J. \& Porse, H. 2011. A decade of change in the seaweed hydrocolloids industry. J. Appl. Phycol. 23:321-335

Bouanati, T., Colson, E., Sébastien Moins,S., Cabrera, J.C, Eeckhaut, I., Raquez, J.M. \& Pascal Gerbaux, P. 2020. Microwaveassisted depolymerization of carrageenans from Kappaphycus alvarezii and Eucheuma spinosum: Controlled and green production of oligosaccharides from the algae biomass. Algal Research, 51:1-10. doi: 10.1016/j.algal.2020.102054

Doty, M.S. 1987. The production and use of Eucheuma. In: Doty, M.A., Caddy, J.F., Santelices, B. (Eds.), Case Studies of Seven Commercial Seaweed Resources. FAO Fish. Tech. Pap., 281 Rome

Fadilah. S. \& Dhini, A.P., 2016. Propagasi Bibit Rumput Laut Gracilaria gigas pada Tahap Kultur Jaringan, Aklimatisasi, dan Pembesaran. Media Akuakultur. $11(2): 1010-1014$.

FAO, 2014. Fao Year book, Fishery and Aquaculture Statistics 2012, Food \& Agriculture Org

FAO. 2012. The state of world fisheries and aquaculture. Opportunities and challenges

FAO. 2013. Yearbookof fishery statistics summary tables. 〈ftp://ftp.fao.org/fi/stat/summary/ default.htm); accessed7.09.13.

FAO. 2018. Meeting the Sustainable Development Goals, Rome.

Ghadiryanfar, M., Rosentrater, K.A., Keyhani, A. \& Omid, M. 2016. A review of macroalgae production, with potential applications in biofuels and bioenergy. Renew. Sust. Energ. Rev., 54:473-481. doi: 10.1016/j.rser.2015.10.020

Godinez-Ortega, J.L., Snoeijs, P., Robledo, D., Freile-Pelegrin ,Y. \& Pedersen, M. 2008. Growth and Pigment Composition in The Red Alga Halymenia floresii Cultured 
Under Different Light Qualities. J. App. Phycolog. 20:253-260.

Hendri, M., Rozirwan. \& Apri, R., 2017., Optimization of Cultivated Seaweed Land Gracilaria sp. Using Vertikultur System. Int. J. Mar. Sci., 7(43):411-422.

Hurd, C.L., Harrison, P. J., Bischof, K., \& Lobban, C.S. 2014. Seaweed Ecology and Physiology. 2nd. Cambridge University Press. doi: 10.1017/CB09781139(92637)

Matthijs, H.C.P., Balke, H., Van Hes, U.M., Kroon, B.M.A., Mur, L.R. \& Binot, R.A., 1996. Application of Light-Emitting Diodes in Bioreactors: Flashing Light Effects and Energy Economy in Algal Culture (Chlorella pyrenoidosa). Biotechnol. Bioeng., 50(1):98-107.

Neish, I.C., 2013., Social and economic dimensions of carrageenan seaweed farming in Indonesia, Soc. Econ. Dimens. Carrageenan Seaweed Farming Fish. Aquac. Tech. Pap. 580:61-89.

Okumura, C., Saffreena, A.N., Rahman, M.A., Hasegawa, H., Miki, O. \& Takimoto, A. 2015. Economic Efficiency of Different Light Wavelengths and Intensities Using LEDs for The Cultivation of Green Microalga Botryococcus braunii (NIES836) for Biofuel Production. Environ. Prog. Sustain. Energ., 34(1):269-275.

Packer, M., 2009. Algal Capture of Carbon Dioxide: Biomass Generation as A Tool for Greenhouse Gas Mitigation with Reference to New Zealand Energy Strategy and Policy. Energy Policy. 37: 3428-3437.

Pramesti, R. 2013. Media Air Laut yang Diperkaya Terhadap Laju Pertumbuhan Gracilaria lichenoides L (Harvey). Bul. Oseanograf. Mar. 2(1):66 -71 doi: 10.14710/buloma.v21.6929

Stewart, H.L. \& Carpenter, R.C. 2003. The Effects of Morphology and Water Flow on Photosynthesis of Marine Macroalgae. Ecology. 84(11):2999- 3012
Suryono, C.A., Irwani, Sabdono, A., Pribadi, R., Setyani, W.A., \& Indarjo, A., 2020. Pertumbuhan Rumput Laut Gracilaria sp. Greville, $\quad 1830 \quad$ (Rhodophyta: Florideophyceae) di Tambak Tidak Produktif Mangunharjo Tugu Semarang. J. Mar. Res., 9(4):369-373 doi: 10.14710/jmr.v9i4.29215

Takahide, Y., Hisayuki, A., Saori., Ryo, I., Akira, M. \& Yutaka, O. 2017. Effects of Light Conditions on The Growth of Commercial Seaweed Undaria piunnatifida. Afr. J. Plant Sci. 11 (6):190-196.

Thanigaivel, S., Chandrasekaran, N., Mukherjee, A. \& Thomas, J. 2016. Seaweeds as an alternative therapeutic source for aquatic disease management. Aquaculture, 464:529-536

Vatsos, I.N. \& Rebours, C., 2015. Seaweed extracts as antimicrobial agents in aquaculture. J. App. Phycol., 27(5):20172035

Wang, Z., Tian, J., Yu, B., Yang, L., \& Sun, Y., 2015., LED Light Spectrum Affects The Photosynthetic Performance of Houttuynia cordata Seedlings. Am. J. Optics Photonics. 3(3):38-42

Wu, H., 2016. Effect of Different Light Qualities on Growth, Pigmen Content, Chlorophyll Fluorescence, and Antioxidant Enzyme Activity in The Red Alga Pyropia haitanensis (Bangiales, Rhodophyta). BioMed Res. Int., 1-8

XU, S.Y., Huang, X. \& Cheong, K.L., 2017. Recent advances in marine algae polysaccharides: isolation, structure, and activities, Mar. Drugs. 15(12):1-16

Yakob, Z., Ali, E., Zainal, A., Mohamad, M., \& Takriff, M.S. 2014. An overview: biomolecules from microalgae for animal feed and aquaculture, J. Biol. Res. 21 (1):110.

Zemke-White, W.L. \& Ohno, M.1999. World seaweed utilization: an end-of century summary. J. App. Phycolog., 11:369-376 